\title{
Importance of Agriculture in Creating Energy Security-A Case Study of Poland
}

\author{
Stanisław Bielski ${ }^{1}$, Renata Marks-Bielska ${ }^{2, * \mathbb{D}}$, Anna Zielińska-Chmielewska ${ }^{3} \mathbb{D}$, Kęstutis Romaneckas ${ }^{4} \mathbb{D}$ and \\ Egidijus Šarauskis ${ }^{4}(\mathbb{D}$ \\ 1 Faculty of Agriculture and Forestry, University of Warmia and Mazury in Olsztyn, M. Oczapowskiego 8, \\ 10-718 Olsztyn, Poland; stanislaw.bielski@uwm.edu.pl \\ 2 Faculty of Economic Sciences, University of Warmia and Mazury in Olsztyn, M. Oczapowskiego 4/300, \\ 10-719 Olsztyn, Poland \\ 3 Institute of Economics, Poznań University of Economics and Business, Al. Niepodległości 10, \\ 61-875 Poznań, Poland; anna.zielinska@ue.poznan.pl \\ 4 Agriculture Academy, Vytautas Magnus University, K. Donelaičio str. 58, 44248 Kaunas, Lithuania; \\ kestutis.romaneckas@vdu.lt (K.R.); egidijus.sarauskis@vdu.lt (E.Š.) \\ * Correspondence: renatam@uwm.edu.pl
}

Citation: Bielski, S.; Marks-Bielska,

R.; Zielińska-Chmielewska, A.;

Romaneckas, K.; Šarauskis, E.

Importance of Agriculture in Creating Energy Security-A Case Study of

Poland. Energies 2021, 14, 2465.

https://doi.org/10.3390/en14092465

Academic Editor:

Alberto-Jesus Perea-Moreno

Received: 30 March 2021

Accepted: 21 April 2021

Published: 26 April 2021

Publisher's Note: MDPI stays neutral with regard to jurisdictional claims in published maps and institutional affiliations.

Copyright: (c) 2021 by the authors. Licensee MDPI, Basel, Switzerland. This article is an open access article distributed under the terms and conditions of the Creative Commons Attribution (CC BY) license (https:// creativecommons.org/licenses/by/ $4.0 /)$

\begin{abstract}
Analyses of statistical data were made and their results discussed in this article to identify the level of Poland's energy security and to determine the role of agriculture in ensuring it. It has been demonstrated that coal continues to be the staple resource for the generation of energy in Poland. The current demands and requirements concerning the reduced consumption of nonrenewable resources and Poland's obligations towards the European Union regarding the production of energy from renewable resources-all these considerations contribute to the promotion of a skillful development of energy crop farming, which, in Poland, is likely to be very successful. Agriculture plays an important role in ensuring Poland's energy security, and this branch of farming can grow dynamically provided adequate legal regulations and promotion are in place. The chief resource for renewable energy generation is biomass. Straw and biogas production in agricultural biogas plants are two solutions whose full energy production potential still awaits to be tapped.
\end{abstract}

Keywords: energy agriculture; biomass; biofuels; renewable energy sources (RES); Poland

\section{Introduction}

The economy needs the essential supply of basic production factors, such as tangible and financial assets, demographic resources, technologies, and organization, as well as energy resources, all of which, in various structural configurations, have determined the economic development so far, and will continue to do so in the future. The selection of the mentioned factors and their mutual proportions depend on the demands of the economy and the associated social expectations. This relationship can be disturbed by certain barriers, such as the scarcity of resources or their spatial distribution not being compatible with the demand [1,2].

Until the 1970s, energy was obtained expansively. Unlimited non-renewable resources were used. As a result of the oil crises in 1973 and 1979-1982, there was a change in thinking about the energy sector. By convention, these events got people talking about the transformation of modern energy, the assumptions of which concerned not only the security of energy supplies (energy security), but also sustainable development. This energy transformation led to a radical change in the previously existing energy system towards a new paradigm of energy production and consumption.

Energy security is a term that has not been clearly defined, making it difficult to measure energy security and to balance its attainment against other policy objectives [3].

The range of energy security has also expanded. There is an increasing emphasis on aspects such as environmental sustainability and energy efficiency. Significant discrepan- 
cies in research are observed in how energy security indexes are framed and constructed [4]. Overall, the concept of energy security is closely related to the policy of sustainable growth, economic factors, the development of energy supply markets, and socio-economic changes in transport and information technologies.

Definitions of energy security emphasize the availability of energy at any time, in different forms, in sufficient amounts, and at relatively low (affordable) prices. Energy security has an internal (balancing the demand and supply of energy, taking into account the environment, consumers, and political as well as economic considerations) and external dimension (meeting the domestic demand for energy, which exceeds the state's energy production) [5].

Energy security is internal (balancing supply and demand, taking into account the environment, consumers, and political and economic requirements) as well as external (covering domestic needs that exceed production). In the short term, energy security refers to the ability of the energy system to react quickly to sudden changes in the supply and demand balance. In the long term, energy security concerns timely investments to ensure energy supplies are in line with economic developments and environmental protection needs [6].

In defining energy security, several approaches can be distinguished, among which, an important place is occupied by the following: political and strategic (also known as geopolitical), and economic. From the geopolitical perspective, attention is drawn to the fact that energy security is a subsystem of national security and should be analyzed both from a political and economic point of view. From an economic point of view, the threats related to the shortage of fuels and interruptions in energy supply are emphasized [7].

Threats to energy security are divided into [1]:

- physical, e.g., temporary or permanent cuts in energy supply from one source or in one region;

- economic, e.g., the dependence of supplies on energy prices;

- others, such as high environmental requirements, which have a significant influence on production, supplies and consumption of crude oil to cite an example.

The event known as the 'Peak-Oil' corresponds to a decline in the world's oil production. This causes price increases and even armed conflicts, which is why some governments fear whether they can ensure the energy security of their states. It is widely believed that the era of cheap energy is long past [8].

Many experts in the global energy industry are increasingly often reporting the geopolitical risk associated with a possible disruption in the world's energy balance, while the developing civilization contributes to a surging demand for energy. If economic growth continues to be forced on the current level, then it is estimated that the global demand for primary energy will increase by $55 \%$ by 2030 . Meanwhile, stocks of fossil fuels are being drastically depleted, and the use of these energy sources is restricted due to ecological considerations. Should the current energy consumption be maintained, non-renewable energy sources could be depleted as soon as the year 2040. This explains why so much emphasis is placed on the development of renewable energy sources (RES), which diminish the reliance on crude oil and the emission of greenhouse gases [9-11].

It is very important for countries and economic and political groups to strive for energy security. Dependence on the supply of energy resources, combined with the risk of rapid increases in their prices, encourages actions to minimize the risks associated with energy supply. This is facilitated by appropriate and effective security policies, economic alliances, or the creation of transnational common energy markets.

Central and Eastern Europe has been and still is highly dependent on Russian supplies of oil and natural gas (about $90 \%$ of Russian natural gas goes to Europe). Russia has long built its international position on the basis of its vast raw material and energy potential. Many of the most recognizable Russian companies on foreign markets are oil companies. Invariably since the 1950s, the European gas market has been a priority in Russia's foreign energy policy. 
In its previous economic and political system, the former Soviet Union had had the greatest influence in the region; thus, the individual countries of Central and Eastern Europe took actions, including cooperation, which would allow them to diversify fuel supplies, as well as to obtain energy from their own sources. An example of this is the region's largest hydropower project (the Iron Gates), built between 1964 and 1972 in Romania and Yugoslavia [12]. Nowadays, there is also an increasing number of different types of activities that contribute to increasing the efficiency of energy use and moving away from energy-intensive production.

The EU's current energy policy, according to which the policies of all EU member states must adhere, concerns both the development of a common energy market and the protection of the natural environment, taxes, trade, and competition. The creation of an internal energy market is carried out indirectly via the harmonization of the law in the member states, and directly through the liberalization of national energy markets. Transparent energy prices have been set up and large grids for the transmission of natural gas and electric power have been made accessible [13]. Energy security is a priority target in Poland. For Poland, the most important issue in this regard is to cover the growing demand for fuels and energy associated with the predicted economic growth while ensuring continuous energy supplies. Other important goals are the maintenance of a high indicator of energy independence, diversification of the energy mix, and diversification of the directions of imported fuel supplies. The latter concerns both crude oil and natural gas. It will be necessary to expand the electric power generation capacity in order to meet the growing demand for electric power. Another important plan in terms of ensuring stable supplies of electric power and diversifying energy sources is to implement nuclear power generation in Poland by the year 2033. Considering the availability of domestic deposits of coal and lignite, the national excavation of coal is projected to maintain a level that will allow the energy sector to meet the demand. The share of coal in electric power generation, however, will be gradually decreased. In 2030, it will decline to 56-60\% and the decreasing trend will continue until 2040 [14].

Mineral resources, including fossil fuels, have long been the main source of energy, first in the form of heat and later as electric power. However, as the mining deposits are being drastically depleted, the goal to develop efficient methods to acquire energy from renewable resources, such as biomass, sun, wind, water, or the earth's thermal resources, is gaining prominence. Given the widespread availability of biomass, which can be obtained as a by-product of many industrial and agricultural processes, it is a renewable energy source with a high growth potential $[9,15,16]$.

Biomass is any organic matter, including biodegradable waste. It is a relatively easy to obtain, natural, and ecological substance that is classified as a renewable energy source. Biomass is also a fuel that is safe for the environment. The use of biomass also contributes to the utilization of waste [17-23].

The Polish energy sector relies heavily on coal and lignite (in 2019, their total share constituted $80 \%$ of all energy carriers used in Poland). As a result, large quantities of air pollutants are generated [24]. Generation of renewable energy is based mainly on biofuels (ca. 80\%). Wind power has a relatively large share (ca. 12\%). Much less energy is produced from water (around $2 \%$ ), biogas (around 3\%), and solar power (ca. 0.6\%). Trace amounts are obtained from the incineration of municipal waste, heat pumps, and geothermal springs [11].

In compliance with the guidelines of the Polish Energy Policy until 2030 [25], the following are indicated as policy targets: improved energy efficiency, increased security of the supplies of fuels and energy, diversification of the structure of electric power generation via the implementation of nuclear power, development in the use of renewable energy sources RES (including biofuels), development of competitive markets of fuels and energy, as well as reduced impact of the energy sector on the environment. 
Supporting the sustainable use of renewable energy sources is emphasized [26]. Among the positive developments to be gained from RES, improved energy security through the diversification of sources of energy is mentioned. In Poland, renewable energy sources can make an important contribution to a better supply of energy in these parts of the country where the energy transmission grid is less developed. Potentially, the biggest RES energy consumer is agriculture, followed by residential housing and transport. Taking measures in line with the adopted energy policy will improve Poland's energy security and decrease the adverse influence of the energy sector on the natural environment.

Agriculture plays various functions. Some are inherent to this sector of economy, but the way they are performed may change (production of raw resources and foods), while others can be important only at certain stages in the economic growth (e.g., supply non-agricultural sectors with financial and labor capital) [27].

The popularity of the multifunctionality of agriculture is due to the awareness spreading in the society, strengthened by scientific research, that agriculture is not only a supplier of the most important products for human existence, food, but also a producer of goods and services that are not priced on the market but are of great importance to humans and the environment. The classification of the most important functions of agriculture is presented in Table 1.

Table 1. Classification of market and non-market functions of agriculture.

\begin{tabular}{|c|c|c|c|}
\hline Production & Social & Cultural & Natural \\
\hline $\begin{array}{l}\text { Commercial: } \\
\text { - foodstuffs intended } \\
\text { for the market, } \\
\text { - agricultural } \\
\text { products being } \\
\text { industrial raw } \\
\text { materials, } \\
\text { - agricultural } \\
\text { products for energy } \\
\text { production, } \\
\text { - tourist services } \\
\text { related to } \\
\text { agricultural } \\
\text { activities. } \\
\text { Non-commercial: } \\
\text { - household food } \\
\text { self-supply, } \\
\text { - means of } \\
\text { production } \\
\text { produced on the } \\
\text { holding for own } \\
\text { needs. }\end{array}$ & $\begin{array}{l}\text { - impact on the } \\
\text { economic viability } \\
\text { and social cohesion } \\
\text { of the countryside, } \\
\text { - an element of social } \\
\text { security for } \\
\text { agricultural families } \\
\text { and some } \\
\text { non-agricultural } \\
\text { families, } \\
\text { - stabilizer of shocks } \\
\text { caused by economic } \\
\text { and institutional } \\
\text { changes (the } \\
\text { so-called external } \\
\text { shock buffer). }\end{array}$ & $\begin{array}{l}\text { - protection and } \\
\text { enrichment of } \\
\text { cultural traditions } \\
\text { in the countryside, } \\
\text { - enrichment of the } \\
\text { national culture, } \\
\text { - enhancing cultural } \\
\text { identity and } \\
\text { diversity at local, } \\
\text { regional, and } \\
\text { national levels, } \\
\text { - shaping cultural } \\
\text { capital, } \\
\text { - protection and } \\
\text { enrichment of the } \\
\text { cultural landscape } \\
\text { of the countryside. }\end{array}$ & $\begin{array}{l}\text { Negative: } \\
\text { - soil and water } \\
\text { pollution with } \\
\text { chemicals and } \\
\text { municipal and } \\
\text { economic sewage, } \\
\text { - soil erosion, } \\
\text { - reducing the } \\
\text { biodiversity of } \\
\text { farmland, } \\
\text { - greenhouse gas } \\
\text { emissions. } \\
\text { Positive: } \\
\text { - preventing the } \\
\text { natural degradation } \\
\text { of agricultural land, } \\
\text { - protection of } \\
\text { agricultural land } \\
\text { biodiversity, } \\
\text { - protection or } \\
\text { improvement of } \\
\text { water conditions in } \\
\text { agricultural areas, } \\
\text { prevention of soil } \\
\text { erosion. }\end{array}$ \\
\hline
\end{tabular}

Source: [28], Reproduced with permission from Wilkin, J. Wielofunkcyjność rolnictwa-nowe ujęcie roli rolnictwa $\mathrm{w}$ gospodarce i społeczeństwie (Multifunctionality of agriculture-A new approach to the role of agriculture in the economy and society). In: Wielofunkcyjność Rolnictwa. Kierunki Badan, Podstawy Metodologiczne i Implikacje Praktyczne; Wilkin, J., Ed.; Instytut Rozwoju Wsi i Rolnictwa Polskiej Akademii Nauk: Warsaw, Poland, 2010, 29. (in Polish). 
Agriculture is now gaining an increasingly important role in ensuring both food and energy security. The changes observed nowadays in farming are already referred to as 'a revolution', and their main drive is the advancement in production technologies, as well as the use of agricultural products for energy purposes. A new branch of agriculture, called energy agriculture, is growing very dynamically [27].

The agricultural sector can play an important role in the transformation of the energy economy in Poland because farming and rural areas in this country are a pool of renewable energy sources (RES) with a promising prospect for further development [29].

Photovoltaic and wind farms can develop in parallel to biogas production [30]. The current situation enables Poland to become more independent from imported energy supplies (mainly natural gas imported from the Russian Federation), to achieve diversification of sources of energy, and to create conditions for the development of dispersed energy generation based on locally available raw materials. These are particularly important steps on the path to reaching the national energy policy's goals [31].

The authors of the manuscript agree that the development of renewable energy generation will make it possible to solve the most urgent problems, such as how to improve the reliability of energy supplies and save organic fuels; to supply local communities with energy; to improve the quality of living and the employment rate of local populations; to ensure sustainable growth; and to fulfill the country's obligations concerning the protection of nature. Acquisition of renewable energy in a decentralized system is one of the options for satisfying the demand for energy in rural areas and on a small scale, so that energy deliveries are reliable, affordable, and environmentally sustainable [32].

The main aim of this study and the analyses therein has been to identify the situation of Poland in terms of energy supplies and energy security on the national scale, as well as the role of agriculture in ensuring energy security.

Detailed aims focused on:

- defining the importance of renewable energy sources in the context of the growing demand for energy,

- indication of the functions of agriculture, with particular emphasis on those related to ensuring energy security

- specifying sources and ascertaining the possibility of obtaining biomass for energy purposes in Poland,

- presenting forecasts of demand for primary and renewable energy in Poland and the demand for rapeseed and cereal grains for bioethanol production for energy,

- submitting of case studies on the directions of use in Poland of different types of biomass (e.g., straw, substrate for biogas plants) and other opportunities to develop renewable energy sources in rural areas.

The achievement of these objectives will allow for systematizing and enriching the existing knowledge on the importance of the place of agriculture in ensuring Polish energy security.

\section{Materials and Methods}

Based on statistical data obtained from the Agricultural Market Agency/National Agricultural Support Center (data on the number of biogas plants and the amount of energy produced, quantitative agricultural use for biogas production), Central Statistical Office (crops of plants used for biofuel production-rapeseed, cereals), and from the Register of Agricultural Biogas Producers (data concerning the activity of agricultural biogas producers) and taking into consideration Poland's energy policy provisions and the obligations towards the European Union, as well as the National Index Target (specifies the minimum share of bio-components and other renewable fuels consumed in all types of transport in the overall volume of liquid fuels and liquid biofuels consumed during a calendar year in road and rail transport, calculated according to calorific value), estimates were made to assess the demand for primary and renewable energy in Poland, as well 
as the demand for canola seeds and cereal grains to produce bioethanol for energy (the demand for this raw material and the needed acreage of fields).

The time scope of the research was 2010-2030. It was mainly determined by the availability of data. The analyses used indicators of structure and dynamics. References were made to the estimates found in the literature concerning the potential production of biomass in Poland. In order to demonstrate the purposefulness, originality, and a new approach to the problem identified and undertaken for research, the method of analysis and criticism of the literature (sources) was used as standard in the first stage of scientific cognition [33]. The manuscript uses the monographic method (allowing for inquiry regarding the essence of the phenomenon, taking into account, first of all, information in the qualitative form about individual types of renewable energy sources from agriculture) and case studies [34-36] (a method used to study a specific phenomenon or related process, usually not typical, to which individual types of RES in rural areasincluding: biomass (straw, agricultural gas), photovoltaics, and wind power), as well as tabular-descriptive and graphic forms of data presentation.

\section{Results and Discussion}

\subsection{Functions of Agriculture}

Agriculture is a complex system, where environmental, economic, cultural, and also political aspects are at play. It is the oldest known form of man's continuous economic activity, which is characterized by constantly evolving multifunctionality. Traditional agriculture was an exceptionally multi-faceted endeavor, having a strong impact on the life of the countryside, the whole economy, and society. The multifunctionality of contemporary agriculture, first and foremost, serves to satisfy important social needs connected with the natural environment, culture, economy, and society. Without any doubt, the principal and most important function of agriculture is production. Other functions arise from the fact that it also produces non-market goods and services [37].

In a narrower approach, the multifunctionality of agriculture concerns the non-food use of agricultural products. This view is associated with the search for other areas where the production function can be used, and, in a certain sense, is the development of the industrial agriculture model, which enables farmers to diversify sources of revenues. At the same time, it ensures food security, as it creates a buffer by maintaining resources in their productive application and allocating surplus agricultural production to nonfood uses [38,39].

Czudec et al. [40] divided functions of agriculture into 'old' ones (performed for centuries) and 'new' ones (which have emerged in recent years). The old functions include food production, the production of raw materials for the food processing industry, and the production of non-food raw materials. The importance of each of these functions has been changing alongside the development of economy; until nowadays, agriculture has turned out to mostly be a producer of raw materials for different branches of industry, while its function as a producer of final food products, which used to be the principal role, now has a relatively small share in the total agricultural production output. Meanwhile, new functions are emerging, such as the protection of the natural environment and biodiversity and the enrichment of landscape values, etc. Production of biomass for energy purposes is another example of a new function of agriculture with an important role to play [41].

Poland possesses substantial potential for the production of solid biomass, also originating from agriculture. Estimates by Igliński et al. [42] suggest that biomass-based energy can be obtained from the following sources:

- generation of energy from surplus straw (92.1 PJ/year if 30\% of the resource is used)

- generation of energy from hay harvested from meadows and pastures laid aside (25 PJ/year at $15 \%$ )

- generation of energy from waste wood from forests ( $87.8 \mathrm{PJ} /$ year at $40 \%)$

- generation of energy from waste wood from orchards (10.9 PJ/year at 30\%) 
- generation of energy from waste wood from roadsides (3 PJ/year at $1.5 \mathrm{~m}^{3} / \mathrm{km} /$ year$2 \mathrm{PJ} /$ year),

- generation of energy from willow (3803 TJ) and miscanthus (3 $650 \mathrm{TJ}$ ) if 20\% of agricultural wasteland and $50 \%$ of fallow land are used.

By using the biomass grown and harvested on energy crop plantations set up on lands unsuitable for agricultural production and biomass from waste, it will be possible to substantially increase the share of RES in the structure of electric and heat energy production.

The need to develop new functions of agriculture has been noticed and appreciated as a result of the growing environmental threats due to excessive use of natural resources, including basic energy resources (crude oil, coal, natural gas). Deposits of non-renewable energy sources are being depleted and the rapidly growing consumption of energy year after year causes an increasingly large emission of pollutants to the environment [40].

\subsection{Renewable Energy Sources in the Context of the Growing Demand for Energy}

For economy to grow, it is necessary to provide a constant supply of energy, the demand for which is growing more and more rapidly [43]. Definitions of energy security encompass three major aspects of security: energy-related, economic (market), and ecological. The aspect connected with energy concerns a balance between the demand and the supply of energy, as well as technical issues including the technical infrastructure and its management. Keeping a country's energy balance entails the ongoing and prospective adjustment of the energy supply to the predicted demand for energy and fuels. Economic and ecological aspects need to be taken into consideration, as well as the capacity to shape the demand without compromising consumers' needs in terms of energy consumption. All energy security definitions emphasize the aspect of environmental protection, hence the need to take into account the role of RES in ensuring energy security. One of the priorities in the development of the energy sector in the near future is to increase the use of renewable energy sources. A greater share of RES in the fuel and energy balance contributes to the improved efficiency of using and saving fossil deposits of energy resources, a better condition of the environment owing to the reduced emissions of pollutants, and decreased total amounts of generated waste [27].

From a longer-term perspective, energy agriculture can ensure that the Polish countryside will be involved in one of the largest innovation areas in the economy. It is estimated that the growth of distributed energy generation (biogas plants and cogeneration systems) in rural municipalities can attract commercial investments to rural areas. This will permanently transform the countryside into an essential player in the electric power and heat generation sector. Energy agriculture, in its part, being the base of raw materials for the industry producing biofuels will enable the residents of rural areas to participate in the benefits arising from a change in the structure of the market of fuels for transportation. Energy agriculture will foster the profitability of production when the sales market expands to cover the two large and crucial markets of food and energy. It is also possible that a strong impulse will appear in the years to follow to develop innovative technologies in agriculture, energy generation and distribution, and in ecology [27].

In most countries around the world, biomass is thought to be a low-emission source of renewable energy. There are many strategies concerning renewable energy with the inclusion of available biomass supplies [44-46]. However, global bioenergy markets can have an impact on the stocks of local food, food processing raw materials, and feeds [47]. Agricultural biomass, as one of the major renewable energy resources, is considered to be the source of the highest energy potential. Depending on the degree to which it is processed, biomass can be divided into primary (annual and perennial energy crops, surplus grass from grasslands not used for animal production) and secondary (waste and by-products from agricultural production and food processing industry, liquid and solid animal excreta, organic waste from the agricultural and food processing industry, e.g., dairy wastewater, slaughter waste, distilleries, glycerine, etc.). The importance of agricultural biomass in 
the development of bioenergy cannot be negated, although there are some discrepancies among the estimates of its potential $[5,48,49]$.

The European Union holds the view that, in order to reduce $\mathrm{CO}_{2}$ emissions more successfully, it is necessary to invest in second-generation biofuels (obtained by processing lignocellulosic raw materials) [50]. The essence of second-generation biofuels lies in the use of waste raw materials, unsuitable for food production. Equally important is their higher quality in comparison with the first-generation of biofuels (produced from food raw materials), which makes them more acceptable by the motor industry and vehicle users. However, the industrial-scale technologies for second-generation biofuel manufacture have not been developed in a completely satisfying way.

As an EU member state, Poland is expected to fulfil its obligations towards this economic organization. Hence, it implements a number of regulations regarding the measures taken under the European common energy policy (e.g., Poland's energy policy until 2030). While undertaking the elaboration of the legal framework and action plans in order to develop the biofuel market in the EU, an assumption was made to dedicate no more than 10 million ha of arable lands in the European Union (slightly over $7 \%$ of all arable land in the EU countries) for the production of biofuels. It is estimated that attaining compliance with the EU and national legal regulations regarding the share of energy from renewable sources in Poland would require allocating a total of 1.7-2.0 million ha of land by the year 2020 for the production of crops used for fuel substitution purposes. This acreage would comprise around 500 thousand ha of soils good enough to grow canola processed to esters, ca. 600 thousand ha of arable land for the cultivation of crops processed to bioethanol, and around 500 thousand of ha under permanent plantations of perennial crops harvested for solid biofuels. In addition, some 300-4000 thousand ha should be dedicated to producing feedstocks for biogas plants, where some of the demand would have to be satisfied with grasses from permanent grasslands. Using raw materials derived from agricultural production for energy purposes creates new challenges to farmers, which often require system solutions. Meanwhile, this option for using agricultural crops stimulates moderate and rational intensification of production and optimization of land use, and is therefore one of the contributing factors to a rational management of the soil resources in Poland [51].

According to the European Union and national obligations, the forecast increase in the demand for primary energy until the year 2030 in Poland will reach ca. $27 \%$ relative to that in 2010. The share of energy from renewable sources in the total primary energy consumption will rise from ca. $6.8 \%$ in 2010 to $12.4 \%$ in 2025 and 2030 (Table 2).

Table 2. Past and forecast of the demand for primary and renewable energy.

\begin{tabular}{|c|c|c|c|c|c|c|}
\hline \multirow{2}{*}{ Specification } & \multirow{2}{*}{ Unit } & \multicolumn{5}{|c|}{ Years } \\
\hline & & 2010 & 2015 & 2020 & 2025 & 2030 \\
\hline Primary energy & Mtoe & 93.2 & 95.8 & 101.7 & 111 & 118.5 \\
\hline Renewable Energy & Mtoe & 6.3 & 8.4 & 12.2 & 13.8 & 14.7 \\
\hline $\begin{array}{l}\text { Share of Renewable } \\
\text { Energy in Total } \\
\text { Primary Energy } \\
\text { Consumption }\end{array}$ & $\%$ & 6.8 & 8.8 & 12.0 & 12.4 & 12.4 \\
\hline
\end{tabular}


The acreage cropped with plants suitable for bioethanol production (starch and sugar products: cereal grains, potato, maize, sugar beet) depends on environmental factors and organization, as production of these raw materials must adhere to the sustainable development criteria [17], but the major constraint could be economic considerations; as such, plantations should be set up mainly on poorer soils, where lower yields are obtained, and therefore costs of bioethanol production are high. Production of methyl esters and fatty acids (biodiesel) encounters similar difficulties. The predicted increase in the demand for esters of higher fatty acids and bioethanol, and consequently the land for growing the necessary raw materials (data presented in Table 3), implies that 1.93 million ha of farmland needs to be secured in 2021 for the production of esters. The domestic demand for canola seeds needs to take into account the acreage of farmland cropped with this plant for food processing needs (around 450,000 ha). Our analysis of the data suggests that, in 2021, over 1.4 million tons of grain will have to be processed into bioethanol. It is difficult to estimate precisely the area of farmland needed to produce so much grain, for example, because different species of cereals can be grown or some bioethanol can be imported $[5,27,37]$.

Table 3. Predicted demand for seeds of oilseed rape grown for energy purposes and grain for the production of bioethanol.

\begin{tabular}{cccc}
\hline Years & $\begin{array}{c}\text { Demand for } \\
\text { Biocomponents } \\
\text { (Thousand } \mathbf{~}^{\mathbf{3}} \text { ) }\end{array}$ & $\begin{array}{c}\text { Demand for Raw } \\
\text { Material (Thousand Mg) }\end{array}$ & $\begin{array}{c}\text { Necessary Acreage of } \\
\text { Crops (Thousand ha) }\end{array}$ \\
\hline 2021 & 1770 & 5133 & 1930 \\
\hline 2022 & 1790 & 5192 & 1952 \\
\hline 2023 & 1811 & 5251 & 1974 \\
\hline 2024 & 1851 & 5369 & 2018 \\
\hline 2020 & & 1421 & 323 \\
\hline 2021 & 517 & 1450 & 413 \\
\hline 2022 & 544 & 1513 & 417 \\
\hline 2023 & 550 & 1530 & 422 \\
\hline 2024 & 556 & 1564 & 431 \\
\hline
\end{tabular}

Source: own calculation based on the National Indicator Target for the years 2021-2024, a forecast assuming the diesel consumption at 20,345 thousand $\mathrm{m}^{3}$ and 6083 thousand $\mathrm{m}^{3}$ petrol [52], providing that consumption in the following years remains similar.

To increase the volume of plant production for energy purposes in Poland, it is suggested to crop fallow and set-aside land (i.e., around 180,000 ha), the share of which varies among the Polish provinces. However, the question of the suitability of worse quality land for the production of energy crops is more complex. Some economic barriers may occur, such as the unprofitability of the production of energy crops on soils classified as worse agricultural complexes. Some of the set-aside farmland in Poland can be used for growing Jerusalem artichoke, a plant with relatively more modest environmental requirements. Biomass from this plant can be dedicated to energy purposes (e.g., for the production of bioethanol; as feedstock for biogas plants, preferably after ensiling; or for briquette and pellet production) [37].

Biomass is a typical local fuel and should be used locally by individual consumers. Using biomass stocks for energy purposes depends on many factors, such as economic incentives or the development of technologies. Until recently, there were no mechanisms in Poland linking the demand for agricultural biomass with agriculture's production capacities, and the inconsistency of measures taken arose from the lack of a strategy. 
However, the question of agricultural biomass was raised in the strategy of sustainable development of the countryside, agriculture, and fisheries for the years 2012-2020 [53].

Another agricultural produce that can be used for energy purposes is straw (ripe or dry stalks of cereal plants, or the dry stems of legumes, flax, or canola). Straw is one of the most important solid biofuels in Poland, and can play an essential role in providing energy in rural areas. There are surplus amounts of this material relative to its potential use for agricultural purposes. Straw-fed small and medium-capacity heating plants can supply energy to individual farmsteads, but also to residential housing estates, schools, municipal office buildings, hotels, etc. [5].

Poland has large stocks of straw because the staple crops grown in this country are cereals and canola. Jarosz [54] estimated the theoretical straw potential quantity at 32 million tons, of which 12,959 thousand tons is the surplus which could be dedicated to energy purposes. In turn, Madej [55] reported the volume of harvested straw in 2020 and made a prediction for 2030. The calculations he presented reveal that the stocks of straw in 2020 will reach 30,553 tons, to increase to 30.86 million tons in 2030. Once the straw needed for animal feeds, litter, being ploughed into soil, and being used as a substrate for mushrooms is deducted, there will be 13,138 thousand tons in 2020 and 14,322 thousand tons in 2030 available for energy purposes.

Based on developed panel models, Gradziuk and co-authors [56] made an attempt to forecast straw surpluses in Poland according to three scenarios: realistic, pessimistic, and optimistic. The predictions implicate that regional differences will continue to exist until 2030. Each of the three analyses suggest a slow increase in straw surplus amounts that will range from 10.6 to $21.9 \%$, depending on the scenario. However, the major problem is the actual availability of straw surplus quantities. The area structure of farms in Poland is an obstacle in this matter (small farms prevail). In the areas with such fragmented area structure, transport of straw is unprofitable. The prevalence of small farms largely limits the use of high-performance straw harvesting presses and affects the potential success of raw material supplies (management of harvests, storage and transport). Potential suppliers of straw for the biofuel sector should be searched for in regions with substantial straw surplus production, exceeding the quantities needed by agriculture until at least the year 2030, and with a suitable area structure of farms (a considerable number of large farms, over 50 ha in area). Three regions meet these criteria: southeastern (comprising the eastern part of the provinces of Lubelskie and Podkarpackie), southwestern (Dolnoślaskie and Opolskie), and northwestern (the provinces of Pomorskie and Zachodniopomorskie).

This, however, does not exclude the possibility of using straw for energy purposes on a local scale (a municipality or a district) in these and other regions. Nevertheless, micro-scale calculations will be needed to define the demand for straw for agricultural purposes more accurately, while taking into consideration different methods of animal housing (with or without litter) and feeding (concentrates or bulk feeds).

While straw is popular renewable energy raw material, it is extremely difficult to accurately determine the balance of straw on a macro-scale (a country, a province) because agricultural production in such large administrative units tends to be concentrated in certain regions. More reliable data are available for smaller administrative entities (municipalities, districts) or even for large-area farms. Such estimates have already been made by scholars [5].

Solid biofuels are also manufactured from grains of different species of cereals, of which oats deserve special attention. Studies conducted by Mółka and ŁapczyńskaKordon [57] and Żabiński et al. [58] show that oat grains have high calorific value and contain very little ash. Moreover, the modest soil and climatic requirements mean that oats gain a considerable advantage over other cereal species.

To meet the growing demand for biomass, it will be necessary to harvest some from dedicated plantations of perennial plant species. Several species could be used for biomass production, but, in practice, their choice will depend on habitat conditions, the costs of acquiring plant material for propagation, the equipment owned by a given farm, and the 
way biomass is to be processed. The most important species are: miscanthus, willow, Virginia fanpetals, reed canary grass, Sakhalin knotweed, and Jerusalem artichoke [59]. However, due to the shortage of biomass from targeted plantations, it is predicted that increasing amounts of straw will be used for energy generation.

There are many reasons why biomass can reduce oil-based energy sources' share of total energy production [18]. An important feature of biomass is the possibility after partial processing to change into heat; gaseous, liquid, and solid fuels; and many other chemical products $[60,61]$. Biomass energy can reduce the consumption of non-renewable energy sources [62]. It can have a positive impact on the economy, environment, society, and energy security [63].

On the other hand, the major barriers to the development of agricultural biomass production include high production costs, long production cycle, and an inadequate level of relevant research. Institutional barriers are mostly the lack of sufficient information, as well as the unsuited organization of the distributed renewable energy sector, which entails the necessity to coordinate actions taken by different sectors and market participants and the need to improve a cohesive policy in this scope.

The impact of biofuels (especially the first-generation ones, such as bioethanol and biodiesel) on the natural environment, food security, and water availability has long been a controversial issue [64-66]. The fact that increasingly more farmland is dedicated to liquid fuel production raises a risk that the food market might suffer, and, consequently, both food and energy prices may rise. The greater demand for land to produce biofuels can also stimulate an increase in prices for agricultural land, which will translate to higher costs of food production.

The more widespread use of distributed, low-capacity local energy plants, producing energy locally and supplying it directly to farms, is another development contributing to energy security. Here, the most useful are renewable energy installations such as biomass boilers, biogas micro-plants, small wind mills, and solar panels. The use of these technologies in agriculture allows farmers to decrease the amounts and costs of purchased energy, as some will be generated on the farm, bringing about measurable financial benefits. It can also help to reduce the noxiousness of agricultural production by using animal or plant production waste, e.g., liquid slurry, for energy purposes. The rational use of these sources means benefits for both a farm and the whole agricultural sector. When farms use energy from renewable sources, they can replace non-renewable resources, which are both increasingly less available and more expensive to farmers, such as hard coal or coke to produce electric power or heat rooms and water; or liquid fuels, e.g., natural gas, liquefied gas, diesel oil, or heating oil used to run combustion engines or for heating. Relations between prices for conventional energy carriers versus energy from RES, as well as the difficulties the conventional energy sector encounters in its efforts to ensure energy security create a chance for the development of renewable energy technologies, which are the most profitable ones at the moment [67].

One of the most prospective directions in the energy use of biomass is believed to be the production of agricultural gas. A biogas plant is an installation which serves specifically to produce biogas from plant biomass, animal waste, or organic waste (e.g., from the food processing industry). Unfortunately, this direction in biomass energy conversion is not popular enough in Poland. A small share of agricultural gas obtained follows from a small number of working biogas plants. The data contained in the Register of Agricultural Biogas Producers, as of 2 January 2021, suggest that there are only 93 registered producers who, in total, own 104 agricultural biogas plants. The annual capacity of all agricultural gas producing installations is $439,293,867.800 \mathrm{~m}^{3} /$ year, and the total installed electric power is 108.458 MWe [68]. This state of matters is associated with both the existing barriers to building agricultural biogas plants (e.g., economic, legal, and technological obstacles) and the availability of raw materials. 
The data in Figure 1 show that in the years 2011-2019, the number of agricultural biogas plants in Poland increased. The dynamics of their formation were characterized by a downward trend. In 2019, the trend was reversed.

The analysis of the data contained in Figure 2 showed that, in the years 2011-2019, the amount of biogas produced and the amount of energy produced by agricultural biogas plants in Poland increased. In 2019, compared to 2011, the amount of biogas produced increased by 269.8 million tons, and the amount of energy produced by biogas plants by 572.9 GWh (Figure 2). However, this state of affairs is not satisfactory. In this regard, the potential in Poland is not well used.

Fermentation of biomass to methane is one of the most efficient lignocellulosic biomass conversion methods. The suitability of biomass for biogas production depends on the yield efficiency per area unit, energy efficiency per biomass unit, and rate of conversion of biomass to gas fuel. In Poland, anaerobic digestion of agricultural biomass generates $13-32 \%$ of biogas produced $[69,70]$. Biogas plants should operate for at least $8000 \mathrm{~h}$ a year. Biomass is produced only during the plant growing season, and its composition varies depending on the physiological process that occur in plants during their growth and development.

Maize silage is now the main plant feedstock used to produce biogas in agricultural biogas plants. Maize is popular raw resource for making biogas because it is grown extensively, has relatively high biomass yield per hectare, is highly suitable for ensiling, and gives a high rate of biomass to biogas conversion. However, the greatest advantage of maize silage compared to other substrates is that it ensures the stable production of biogas and methane, which largely facilitates the dosing of a substrate to a digestion chamber and stabilizes the operation of this cogeneration unit [71].

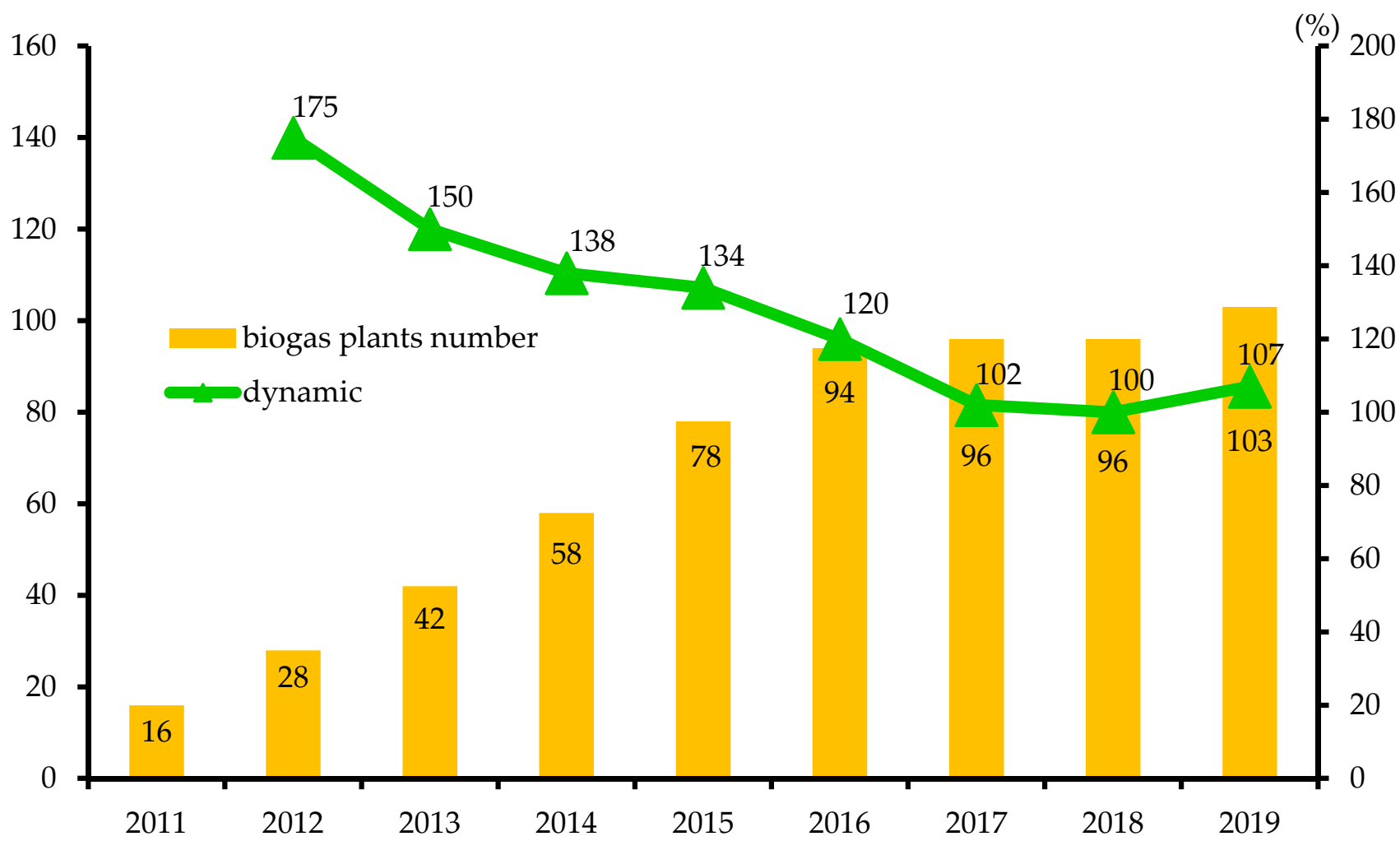

Figure 1. Biogas plants number and the dynamics of their creation. Source: based on Agricultural Market Agency/National Agricultural Support Center data. 


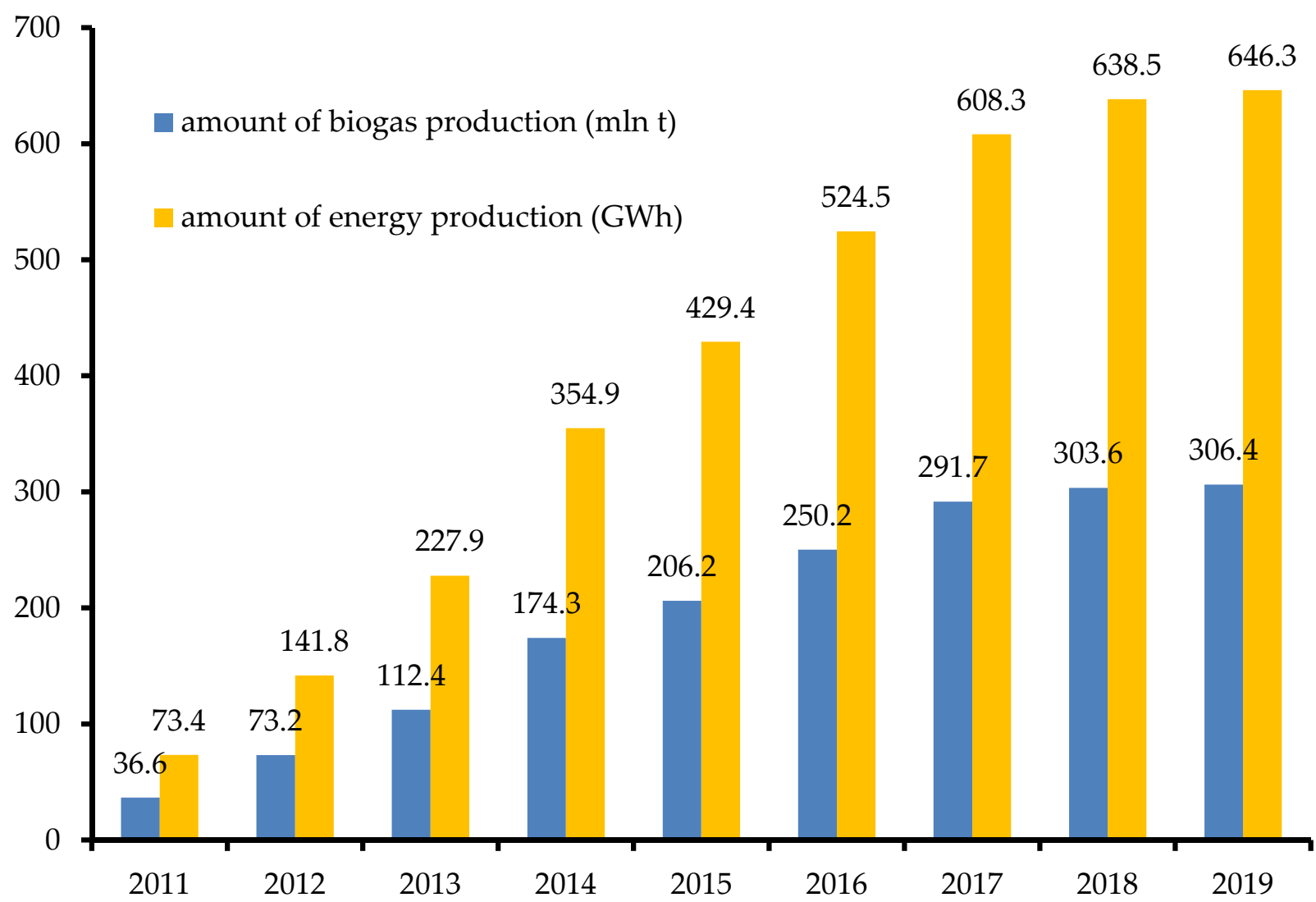

Figure 2. Production of agricultural biogas and electrical energy in agricultural biogas plants in Poland. Source: based on Agricultural Market Agency/National Agricultural Support Center data.

Costs of acquiring the raw material, as well as the competitive use of maize for food and feeds, encourage the search for alternative types of biomass, plant waste, or waste from the food processing industry to use in anaerobic fermentation processes run in agricultural biogas plants.

Biogas plants can make a very good contribution to the national energy generation capacity, especially as the theoretical potential yield has been estimated at 5 billion $\mathrm{m}^{3}$ of biogas per year, whereas the actual potential output based on by-products from agriculture and food processing is said to be around 1.7 billion $\mathrm{m}^{3}$ of biogas per year. Such quantities of biogas, after refining, could cover around $10 \%$ of the demand for gas, or totally satisfy the demand for gas in rural areas [72]. Large-scale biogas production can translate to the country's improved energy security or lower gas deficit and-in the more distant future-it may enable the country to become independent from imported gas and to fulfil its obligations towards the European Union regarding the generation of energy from RES.

Among all renewable energy sources, biogas plants are thought to be most efficient installations. Assuming the use of the same capacity energy generators, a biogas plant can generate three times more energy than a wind farm in a year. Biogas plants can produce energy all year round, in contrast to other RES (e.g., wind farms, which depend on vertical flows of air).

Agricultural biogas plants let farmers satisfy their own demand for energy and sell possible surplus energy to the energy grid. In addition, the digestate can be re-used for soil fertilization. Agricultural biogas plants can stimulate the economy, help to ensure the country's energy security, and create a new opportunity for farmers, especially when facing possibly limited support for agricultural production from the Common Agricultural Policy. As well as helping to decrease environmental pollution, the construction of biogas plants is of the utmost importance for the diversification and increase of incomes from farms [27]. 
Piwowar [31] provides the information that 88 new installations for agricultural biogas production were built in 2011-2018. In the same time period, the amount of produced biogas increased by 266.918 billion $\mathrm{m}^{3}$. Between 2011 and 2018, a total of 18,600,441 Mg of raw materials was used to supply biogas plants, of which, liquid slurry made up around $25 \%(4,583,524 \mathrm{Mg})$. Production of agricultural biogas in Poland is still in its early phase and is characterized by dynamic changes (e.g., the number of installation, amounts of consumed raw materials, changes in the structure of used substrates, etc.). The development of the biogas market in Poland is strictly connected with the legal and economic conditions as well as administrative decisions concerning the location of biogas plants or financial support for investment projects or the maintenance (production) of operating facilities. Agricultural biogas plants are an essential element in the evolution of the Polish energy market towards the decentralized (distributed) model.

Other than the production of biomass and biogas, rural areas with suitable wind patterns can also be chosen as location for devices converting the kinetic energy of wind to electricity. Wind energy generation is now the leader of 'green' technologies. In terms of its market share, it is far ahead of other renewable energy sources and is also a more rapidly developing technology (e.g., in comparison with hydroenergy generation or biomass used for energy purposes). Thus, it is the leading and prospective technology in the struggle against global warming.

There is a potential in rural areas of Poland to install several thousand small wind turbines on agricultural farms. This could significantly support the national plans to satisfy Poland's international obligations regarding the reduction of $\mathrm{CO}_{2}$ emissions and the combustion of fossil fuels in commercial energy generation plants. It could also bring about many benefits to society, for example, creating conditions for the industrial manufacture of elements needed for the construction of small wind turbines, greater interest in the issues of using renewable energy sources in the countryside, the development of relevant research, and the construction and research work in the scope of building small wind turbines and farms. According to Turowski and Nowowiejski [73], by installing a wind turbine, a farmer can reduce the cost of buying electric power by $50 \%$, and a farm can increase its general profitability by selling the surplus electric energy to an energy distributor.

The development of renewable energy sources with the inclusion of the agricultural sector and rural areas is both a necessary and promising idea. However, it encounters various obstacles, such as the lack of a stable state policy towards the RES sector, legal and financial constraints, and limitations due to the negative influence on the natural environment or human health. For example, solar and wind energy can improve Poland's energy security. However, when all the aforementioned restrictions are considered, the role of these sources need not be overestimated in Poland's energy mix (although wind farms, which are to be constructed on the Baltic Sea, are a promising prospect).

An opportunity for the development of the renewable energy sector in Poland arises from investments in distributed energy micro-sources rather than from building large power plants. Rural areas (around 93\% of Poland's territory) are the principal location of renewable energy sources.

Among the biggest barriers to the development of the wind power sector in rural areas, the following are mentioned most frequently: legal regulations; lagging procedures; and a lack of clearly defined regulations, the interpretation of which mainly depends on the good will and favor of local administrative authorities, and on the advance mechanisms. In addition, a decision to localize a wind farm can also be affected by social protests evoked by the fact that wind power plants generate noise that can be noxious to local residents, and wind turbines are said to spoil the landscape. Investors are mostly worried that they will not be able to obtain a permit for a power grid connection. The ecological aspect of wind turbines and their negative impact on the natural environment are still debatable questions. In terms of ecology, attention is drawn to the adverse effect of turbines on migrating birds, killed by a turbine's blades. In regard to the effect on the surroundings, the main argument against building wind farms is the so-called wind turbine syndrome, consisting of problems 
with sleeping and concentrating, as well as headaches and dizziness. Studies conducted on this problem (e.g., in the U.S.A., U.K., the Netherlands, and Denmark) have revealed that the syndrome may appear if residential houses are situated at a distance of less than $3 \mathrm{~km}$ from a wind farm. The reluctance of farmers to allow the construction of wind turbines on their land has been strengthened by instances of unfair practices of investors towards land owners (vague, unclear terms of contracts, unclear participation in profits, interception of land by investors, etc.) [74]. The intensive increase of wind power capacity in Poland is observed to have slowed down since 2017.

There are also proponents and opponents of photovoltaic power generation, which, until recently, was most often used to provide power to low-power devices in sites with difficult access to the power grid (e.g., traffic lights, street lights, notice boards, emergency power systems, small trade equipment, environmental monitoring equipment, and telecommunication relays). Nowadays, there are photovoltaic farms generating energy for sale. Abromas [75] classified wind turbines, hydropower plants, and solar power plants as the power sector facilities causing the strongest visual impact on the countryside landscapes. This author expressed the opinion that the visual quality of scenery is one of the non-tangible assets of people's living environment that defines the quality of life.

According to Kryszk and Kurowska [41], the construction of large photovoltaic farms in Poland can be helped by the rather neutral influence they have on the surroundings. They are less intrusive on the landscape, and their energy stocks are replenished by natural processes, which means they can be considered to be inexhaustible. In contrast to wind farms, photovoltaic farms are more acceptable to society. Photovoltaic panels are most often placed on the roofs of houses and other buildings, sets of traffic lights, street lights, etc. It is very often just a small addition to an existing object.

Although photovoltaic power recorded the highest increase in installed power among all RES in Poland in 2019, and is nowadays the major area for investment in the renewable energy sector, it also has some opponents. While their price has been decreasing for several years now, solar panels are still rather expensive. They can cover large areas when designed for mass use. Another controversial issue is whether their production can be seen as ecofriendly. Obviously, to some extent, it pollutes the environment, but it is unrealistic to hope for $100 \%$ ecological generation of power on an industrial scale. Solar power plants do not generate and store energy at night, but then conventional power plants can experience stopovers leading to power cuts. It is therefore advisable to run a rational policy regarding the management of power resources. Considering opportunities and limitations in the development of renewable energy sources in rural areas in Poland, the measures planned to be taken in this area should be preceded by a thorough, multi-criteria analysis.

\section{Conclusions}

The results of the research and analyses carried out showed that the production of energy crops will require an increasing acreage of agricultural land. In order to meet the obligations adopted under the European Union energy policy and a compatible national policy in this area, it is also necessary to use imported biocomponents. It should be emphasized that the conducted research and analyses also have limitations. Among others, the authors yield variability, fuel consumption variability (diesel oil and petrol), and the instability of legal regulations (assumptions regarding the share of liquid biocomponents are established for 2-3 years and are variable).

The actual threats to energy security force us to invest in new technologies, especially in renewable energy sources, including the conversion of biomass and the distribution of energy generation systems. The current tendencies show that renewable energy is going to be the most dynamically developing sector in rural areas. Nowadays, agriculture plays the roles of both food producer and supplier of biomass for energy purposes. Rural areas are where most investments in renewable energy sources are localized. 
Despite the ongoing changes, not all the energy potential of Polish agriculture is taken advantage of. Agriculture will continue to play an important role in the accomplishment of goals associated with renewable energy sources. Besides supplying raw materials, the countryside can also function as the place where energy resources are processed, and this will often entail creating local supplies of energy.

Production of raw materials for energy purposes has become one of the principal, commercial roles of agriculture, which plays an important part in the multi-functional development of the countryside, where farmers can earn additional revenues from selling energy raw materials. Initially, it was assumed that the production of biofuels for personal use would decrease the costs of agricultural production. However, despite the extremely simple technology, few farmers have decided to launch the production of biofuel to be used on their own farms. The lack of financial support for energy production considerably limits the possibilities of any further growth in the production of biomass by agriculture.

Assumptions indicate that the global food demand will have doubled by 2050 . The current agricultural policy and the policy for the development of rural areas are increasingly often perceived as key instruments in helping to face 'the new challenges', which include climate change, renewable energy, water management, and biological diversity. Due to their dispersed character and the use of locally available resources, renewable energy sources can become a contributing factor to increasing energy security and to decreasing the costs of energy. The impact of biomass on the agricultural market will be moderate and will be mostly due to the growing use of second-generation biofuels, improved efficiency of the production of biomass in other sectors, and gradual changes in land use.

Food-producing agriculture is increasingly transforming into an agriculture producing raw materials for energy purposes. It is highly possible that this shift will cause a change in the ratio of food prices to prices of different forms of energy. The emergence of a new market of agricultural products (used for energy generation) can enable farmers to increase agricultural production considerably and put to use all agricultural land. There is also a possibility to manage the surplus output of agricultural raw materials, especially of inferior quality, which are unsuitable for animal or human consumption. For many farmers, renewable energy sources are a chance to rationalize production. From the point of view of the whole country, they create an opportunity to meet the international obligations such as Directive 2009/28/EC of the European Parliament and the Council of 23 April 2009 on the promotion of the use of energy from renewable sources.

There is a need for a holistic approach to the problem of using biomass for energy purposes. This means that the issue should be explored in its entirety, taking into account agriculture, the food industry, economics, the energy sector, and the natural environment. It is also necessary to elaborate specific solutions for the rational use of biomass in the production of energy and fuels under the framework of energy agriculture, which can turn into an important element of the sustainable cost-effectiveness of agricultural production.

Author Contributions: Conceptualization, R.M.-B., S.B., A.Z.-C., K.R. and E.Š.; methodology, R.M.-B. and S.B.; formal analysis, R.M.-B., S.B., A.Z.-C., K.R. and E.Š.; investigation, R.M.-B., S.B., A.Z.-C., K.R. and E.Š.; data curation, R.M.-B., S.B. and A.Z.-C.; writing-original draft preparation, R.M.-B., S.B., A.Z.-C., K.R., and E.Š. ; writing-review and editing, R.M.-B., S.B., A.Z.-C., K.R., and E.Š.; supervision, S.B. and R.M-B; project administration, R.M.-B. and S.B. All authors have read and agreed to the published version of the manuscript.

Funding: The results presented in this paper were obtained as part of a comprehensive study financed by the University of Warmia and Mazury in Olsztyn (grant No. 30.610.013-110). The project was financially supported by the Minister of Science and Higher Education in the range of the program entitled "Regional Initiative of Excellence" for the years 2019-2022, Project No. 010/RID/2018/19, amount of funding 12,000,000 PLN.

Institutional Review Board Statement: Not applicable; for studies not involving humans or animals. 
Informed Consent Statement: All authors.

Data Availability Statement: The available data of public statistics were used.

Conflicts of Interest: The authors declare no conflict of interest.

\section{References}

1. Tarajkowski, J. (Ed.) Czynnik Energia w Polityce Gospodarczej (The Energy Factor in Economic Policy); Akademia Ekonomiczna w Poznaniu: Poznań, Poland, 2010. (In Polish)

2. Szturo, M.; Włodarczyk, B.; Burchi, A.; Miciuła, I.; Szturo, K. Improving relations between a state and a business enterprise in the context of counteracting adverse effects of the resource curse. Sustainability 2021, 13, 1067. [CrossRef]

3. Winzer, C. Conceptualizing energy security. Energy Policy 2012, 46, 36-48. [CrossRef]

4. Ang, B.W.; Choon, W.L.; Ng, T.S. Energy security: Definitions, dimensions and indexes. Renew. Sustain. Energy Rev. 2015, 42, 1077-1093. [CrossRef]

5. Marks-Bielska, R.; Bielski, S.; Novikova, A.; Romaneckas, K. Straw stocks as a source of renewable energy. A case study of a district in Poland. Sustainability 2019, 11, 4714. [CrossRef]

6. Energy Charter Secretariat. International Energy Security: Common Concept for Energy Producing, Consuming and Transit Countries; Energy Charter Secretariat: Brussels, Belgium, 2015; Available online: https://www.energycharter.org/fileadmin/ DocumentsMedia/Thematic/International_Energy_Security_2015_en.pdf (accessed on 8 April 2021).

7. Zajaczkowska, M. The Energy Union and European Union Energy security. Ekon. Prawo Econ. Law 2018, 17, 319-328. [CrossRef]

8. Escobar, J.A.; Lora, E.E.; Venturini, O.J.; Yánez, E.; Castillo, E.F.; Almazán, O. Biofuels: Environment, technology and food security. Renew. Sustain. Energy Rev. 2009, 13, 1275-1287. [CrossRef]

9. Chen, W.-H.; Budzianowski, W.; Lee, K.T. Preface-sustainable biofuels. Energy Convers. Manag. 2017, 141, 1. [CrossRef]

10. Rosales-Calderon, O.; Arantes, V. A review on commercial scale high value products that can be produced alongside cellulosic ethanol. Biotechnol. Biofuels 2019, 12, 240. [CrossRef]

11. Marks-Bielska, R.; Bielski, S.; Pik, K.; Kurowska, K. The importance of renewable energy sources in Poland's energy mix. Energies 2020, 13, 4624. [CrossRef]

12. Creţan, R.; Vesalon, L. The Political Economy of Hydropower in the Communist Space: Iron Gates Revisited. J. Econ. Hum. Geogr. 2017, 108, 688-701. [CrossRef]

13. Miciuła, I.; Wojtaszek, H.; Bazan, M.; Janiczek, T.; Włodarczyk, B.; Kabus, J.; Kana, R. Management of the energy mix and emissivity of individual economies in the European Union as a challenge of the modern world climate. Energies 2020, 13, 5191. [CrossRef]

14. Ministerstwo Aktywów Państwowych. Krajowy Plan na Rzecz Rozwoju Energii i Klimatu na Lata 2021-2030. Założenia i Cele oraz Polityki Działania (National Plan for the Development of Energy and Climate for the Years 2021-2030. Assumptions, Goals and Policies); Ministerstwo Aktywów Państwowych: Warsaw, Poland, 2019. Available online: https://www.gov.pl/web/aktywa-panstwowe/ krajowy-plan-na-rzecz-energii-i-klimatu-na-lata-2021-2030-przekazany-do-ke (accessed on 13 January 2021). (In Polish)

15. Li, Y.; Rezgui, Y.; Zhu, H. District heating and cooling optimization and enhancement-Towards integration of renewables, storage and smart grid. Renew. Sustain. Energy Rev. 2017, 72, 281-294. [CrossRef]

16. Ymeri, P.; Gyuricza, P.; Fogarassy, C. Farmers' attitudes towards the use of biomass as renewable energy-A case study from Southeastern Europe. Sustainability 2020, 12, 4009. [CrossRef]

17. The European Parliament and the Council of the European Union. 2009/28/ec of the European Parliament and of the Council of 23 April 2009 on the Promotion of the Use of Energy from Renewable Sources and Amending and Subsequently Repealing Directives 2001/77/EC and 2003/30/EC. 2009. Available online: https:/ / eur-lex.europa.eu/legal-content/EN/TXT/PDF/?uri=CELEX: 32009L0028 (accessed on 1 January 2021).

18. Gokcol, C.; Dursunb, B.; Alboyacic, B.; Sunan, E. Importance of biomass energy as alternative to other sources in Turkey. Energy Policy 2009, 37, 424-431. [CrossRef]

19. Muresan, A.A.; Attia, S. Energy efficiency in the Romanian residential building stock: A literature review. Renew. Sustain. Energy Rev. 2017, 74, 349-363. [CrossRef]

20. Bildirici, M.; Özaksoy, F. An analysis of biomass consumption and economic growth in transition countries. Econ. Res. Ekon. Istraz. 2018, 31, 386-405. [CrossRef]

21. Contescu, C.I.; Adhikari, S.P.; Gallego, N.C.; Evans, N.D.; Biss, B.E. Activated carbons derived from high-temperature pyrolysis of lignocellulosic biomass. C J. Carbon Res. 2018, 4, 51. [CrossRef]

22. Mehedintu, A.; Sterpu, M.; Soava, G. Estimation and forecasts for the share of renewable energy consumption in final energy consumption by 2020 in the European Union. Sustainability 2018, 10, 1515. [CrossRef]

23. Soltero, V.M.; Chacartegui, R.; Ortiz, C.; Velázquez, R. Potential of biomass district heating systems in rural areas. Energy 2018, 156, 132-143. [CrossRef]

24. Zawalińska, K.; Kinnunen, J.; Gradziuk, P.; Celińska-Janowicz, D. To whom should we grant a power plant? Economic effects of investment in nuclear energy in Poland. Energies 2020, 13, 2687. [CrossRef] 
25. Ministerstwo Gospodarki. Polityka Energetyczna Polski do 2030 Roku. (Poland's Energy Policy until 2030); Ministerstwo Gospodarki: Warsaw, Poland, 2009. Available online: http://www.pigeor.pl/media/js/kcfinder/upload/files/Polityka-energetyczna-Polskido-2030r.pdf (accessed on 8 January 2021). (In Polish)

26. Bórawski, P.; Bełdycka-Bórawska, A.; Jankowski, K.; Dubis, B.; Dunn, J.W. Development of wind energy market in the European Union. Renew. Energy 2020, 161, 691-700. [CrossRef]

27. Marks-Bielska, R.; Bielski, S. Wzrost roli rolnictwa w zapewnieniu bezpieczeństwa energetycznego kraju (Increased role of agriculture in ensuring energy security of the country). Wieś Rol. 2013, 4, 149-160. Available online: http:/ / kwartalnik.irwirpan. waw.pl/dir_upload/photo/ec954147455553bdf7523fe89e49.pdf (accessed on 9 January 2021). (In Polish).

28. Wilkin, J. Wielofunkcyjność rolnictwa-nowe ujęcie roli rolnictwa w gospodarce i społeczeństwie (Multifunctionality of agriculture-A new approach to the role of agriculture in the economy and society). In Wielofunkcyjność Rolnictwa. Kierunki Badan, Podstawy Metodologiczne i Implikacje Praktyczne; Wilkin, J., Ed.; Instytut Rozwoju Wsi i Rolnictwa Polskiej Akademii Nauk: Warsaw, Poland, 2010; pp. 17-40. (In Polish)

29. Hernik, J.; Noszczyk, T.; Rutkowska, A. Towards a better understanding of the variables that influence renewable energy sources in eastern Poland. J. Clean. Prod. 2019, 241, 118075. [CrossRef]

30. Jerez, S.; Tobin, I.; Turco, M.; Jiménez-Guerrero, P.; Vautard, R.; Montávez, J.P. Future changes, or lack thereof, in the temporal variability of the combined wind-plus-solar power production in Europe. Renew. Energy 2019, 139, 251-260. [CrossRef]

31. Piwowar, A. Agricultural biogas-An important element in the circular and low-carbon development in Poland. Energies 2020, 13, 1733. [CrossRef]

32. Panwar, N.L.; Kaushik, S.C.; Kotharia, S. Role of renewable energy sources in environmental protection: A review. Renew. Sustain. Energy Rev. 2011, 15, 1513-1524. [CrossRef]

33. Luo, N.; Olsen, T.L.; Liu, Y. A Conceptual Framework to Analyze Food Loss and Waste within Food Supply Chains: An Operations Management Perspective. Sustainability 2021, 13, 927. [CrossRef]

34. Mitchell, J.C. Case and situation analysis. Sociol. Rev. 1983, 51, 187-211. [CrossRef]

35. Meyer, C.B.A. Case in Case Study Methodology. Field Methods 2001, 13, 329-352. [CrossRef]

36. Eisenhardt, K.M. Building Theories from Case Study Research. Acad. Manag. Rev. 1989, 14, 532-550. [CrossRef]

37. Marks-Bielska, R. Ewolucja Rynku Ziemi Rolniczej w Polsce (Evolution of Agricultural Land Market in Poland); Wydawnictwo Uniwersytetu Warmińsko-Mazurskiego w Olsztynie: Olsztyn, Poland, 2020. (In Polish)

38. Czyżewski, B.; Matuszczak, A.; Grzelak, A.; Guth, M.; Majchrzak, A. Environmental sustainable value in agriculture revisited: How does Common Agricultural Policy contribute to eco-efficiency? Sustain. Sci. 2020, 16, 137-152. [CrossRef]

39. Zielińska-Chmielewska, A. In search of eco-efficiency indicators. The case of chosen food processing enterprises in Poland. In Risk Management-An Interdisciplinary Approach; Brodowska-Szewczuk, J., Ed.; Wydawnictwo Naukowe Uniwersytetu PrzyrodniczoHumanistycznego w Siedlcach: Siedlce, Poland, 2020; pp. 117-134. Available online: http://hdl.handle.net/11331/3430 (accessed on 8 January 2021).

40. Czudec, A.; Kata, R.; Miś, T.; Zając, D. Miejsce rolnictwa w gospodarce i współczesne koncepcje jego rozwoju (The place of agriculture in the economy and contemporary concepts of its development). In Rola Lokalnych Instytucji w Przekształceniach Rolnictwa o Rozdrobnionej Strukturze Gospodarstw; Czudec, A., Kata, R., Miś, T., Zając, D., Eds.; Wydawnictwo Uniwersytetu Rzeszowskiego: Rzeszów, Poland, 2008; pp. 19-42. (In Polish)

41. Kryszk, H.; Kurowska, K. Fotowoltaika jako źródło energii odnawialnej i nowy obszar aktywności na obszarach wiejskich (Photovoltaics as a source of renewable energy and a new area of activity in rural areas). Studia Obsz. Wiejskich Reg. Wymiar Przemian Pol. Wsi Asp. Społeczne Sr. 2014, 35, 255-272. (In Polish)

42. Igliński, B.; Cichosz, M.; Skrzatek, M.; Buczkowski, R. Potencjał energetyczny biomasy na gruntach ugorowanych i nieużytkach w Polsce (Energy potential of biomass on fallow land and wasteland in Poland). Inż. Ochr. Sr. 2018, 21, 79-87. (In Polish) [CrossRef]

43. Vysochyna, A.; Stoyanets, N.; Mentel, G.; Olejarz, G. Environmental determinants of a country's food security in short-term and long-term perspectives. Sustainability 2020, 12, 4090. [CrossRef]

44. Zhang, C.; Xie, G.; Li, S.; Ge, L.; He, T. The productive potentials of sweet sorghum ethanol in China. Appl. Energy 2010, 87, 2360-2368. [CrossRef]

45. Sultana, A.; Kumar, A. Optimal siting and size of bioenergy facilities using geographic information system. Appl. Energy 2012, 94, 192-201. [CrossRef]

46. Viana, H.; Cohen, W.B.; Lopes, D.; Aranha, J. Assessment of forest biomass for use as energy. GIS-based analysis of geographical availability and locations of woodfired power plants in Portugal. Appl. Energy 2010, 87, 2551-2560. [CrossRef]

47. Huang, H.J.; Ramaswamy, S.; Al Dajani, W.; Tschirner, U.; Cairncross, R.A. Effect of biomass species and plant size on cellulosic ethanol: A comparative process and economic analysis. Biomass Bioenergy 2009, 33, 234-246. [CrossRef]

48. Perea-Moreno, M.-A.; Samerón-Manzano, E.; Perea-Moreno, A.J. Biomass as renewable energy: Worldwide Research Trends. Sustainability 2019, 11, 863. [CrossRef]

49. Marks-Bielska, R.; Kurowska, K.; Kryszk, H. The role of agriculture in ensuring energy security in Poland. In Research for Rural Development 2014. Annual 20th International Scientific Conference Proceedings; Latvia University of Agriculture: Jelgava, Latvia, 2014; pp. 191-198. Available online: https:/ /lufb.llu.lv/conference/Research-for-Rural-Development/2014/LatviaResearchRuralDevel2 0th_volume2-191-198.pdf (accessed on 23 March 2021). 
50. Orecchini, F.; Zuccari, F.; Santiangeli, A.; Dell'Era, A.; Bauen, A. Energy Security in the European Union. The European Energy System. Achieving Sustainability and Security; Edizioni Guerini e Associati: Milano, Italy, 2014; Available online: https: / / books.google.pl/books?id=auhaBAAAQBAJ\&pg=PT130\&lpg=PT130\&dq=Renewable+Energy+Changed +The+World +20 11,+European+Union, +Luxembourg.\&source=bl\&ots=QkKg8_r_zq\&sig=ACfU3U2wzVu4EV9uZTF7ZorM9HFzMq8zAg\& $\mathrm{hl}=\mathrm{pl} \& \mathrm{sa}=X \& v e d=2 \mathrm{ahUKEwjjm9fnhvLoAhXIs4sKHcanDnsQ6AEwCnoECAoQLg \# v=onepage \& q=Renewable \% 20Energy} \mathrm{\% 20}$ Changed\%20The\%20World\%202011\%2C\%20European\%20Union\%2C\%20Luxembourg.\&f=false (accessed on 8 January 2021).

51. Krasowicz, S.; Oleszek, W.; Horabik, J.; Dębicki, R.; Jankowiak, J.; Stuczyński, T.; Jadczyszyn, J. Racjonalne gospodarowanie środowiskiem glebowym Polski (Rational management of the soil environment of Poland). Pol. J. Agron. 2011, 7, 43-58. Available online: https://www.iung.pl/PJA/wydane/7/PJA7_5.pdf (accessed on 8 January 2021). (In Polish).

52. Polska Organizacja Przemysłu i Handlu Naftowego. Przemysł i Handel Naftowy Raport Roczny POPiHN (Oil Industry and Trade POPiHN Annual Report) 2019. 2020. Available online: https://popihn.pl/wp-content/uploads/2021/01/Raport-za-2019.pdf (accessed on 8 January 2021).

53. Strategia Zrównoważonego Rozwoju Wsi, Rolnictwa i Rybactwa na Lata 2012-2020 (Strategy for the Sustainable Development of Rural Areas, Agriculture and Fisheries for the Years 2012-2020). 2012. Available online: https:/ /www.gov.pl/web/rolnictwo/ strategia-zrownowazonego-rozwoju-wsi-rolnictwa-i-rybactwa-na-lata-2012-2020 (accessed on 8 January 2021). (In Polish)

54. Jarosz, Z. Potencjał techniczny słomy w Polsce i efekty środowiskowe jej alternatywnego wykorzystania (The technical potential of straw in Poland and the environmental effects of its alternative use). Roczn. Nauk. SERiA 2016, 8, 84-89. Available online: http:// yadda.icm.edu.pl/yadda/element/bwmeta1.element.agro-1b39527f-0a10-4f94-9dad-389d8bd659d2/c/18-1-Jarosz.pdf (accessed on 8 January 2021). (In Polish).

55. Madej, A. Bilans słomy w Polsce w latach 2010-2014 oraz prognoza do 2030 roku (Straw balance in Poland in 2010-2014 and forecast until 2030). Stow. Ekon. Rol. Agrobiz. 2016, 18, 163-168. (In Polish)

56. Gradziuk, P.; Gradziuk, B.; Trocewicz, A.; Jendrzejewski, B. Potential of straw for energy purposes in in Poland-Forecasts based on trend and causal models. Energies 2020, 13, 5054. [CrossRef]

57. Mółka, J.; Łapczyńska-Kordon, B. Właściwości energetyczne wybranych gatunków biomasy (Energy properties of selected biomass species). Inż. Rol. 2011, 15, 141-147. Available online: https://ir.ptir.org/artykuly/pl/131/IR(131)_3075_pl.pdf (accessed on 8 January 2021). (In Polish).

58. Żabiński, A.; Sadowska, U.; Wcisło, G. Ciepło spalania ziarniaków zbóż o obniżonych cechach jakościowych (Heat of combustion of grain kernels of reduced quality characteristics). Inż. Rol. 2012, 16, 353-359. Available online: http://yadda.icm.edu.pl/yadda/ element/bwmeta1.element.baztech-article-BAR0-0067-0061/c/httpir_ptir_orgartykulypl136ir28136293187pl.pdf (accessed on 8 January 2021). (In Polish).

59. Kuś, J.; Faber, A. Produkcja roślinna na cele energetyczne a racjonalne wykorzystanie rolniczej przestrzeni produkcyjnej Polski (Plant production for energy purposes and the rational use of the agricultural production space in Poland). In Przyszłość Sektora Rolno-Spożywczego i Obszarów Wiejskich; Harasim, A., Ed.; Wyd. IUNG-PIB: Puławy, Poland, 2009; pp. 63-76. (In Polish)

60. Dodić, S.N.; Zelenović Vasiljević, T.; Marić, R.M.; Kosanović, A.J.R.; Dodić, J.M.; Popov, S.D. Possibilities of application of waste wood biomass as an energy source in Vojvodina. Renew. Sustain. Energy Rev. 2012, 16, 2355-2360. [CrossRef]

61. Khan, S.; Paliwal, V.; Pandey, V.; Kumar, V. Biomass as renewable energy. Int. Adv. Res. J. Sci. Eng. Technol. 2015, 2, 301-304. Available online: http:/ / www.iarjset.com/upload/2015/si/ncree-15/IARJSET\%2063\%20P188.pdf (accessed on 8 January 2021).

62. Cao, Y.; Pawłowski, A. Biomass as an answer to sustainable energy. Opportunity versus challenge. Environ. Prot. Eng. 2013, 39, 153-161. [CrossRef]

63. Vassilev, S.V.; Vassileva, C.G.; Vassilev, V.S. Advantages and disadvantages of composition and properties of biomass in comparison with coal: An overview. Fuel 2013, 158, 330-350. [CrossRef]

64. Koh, L.P.; Ghazoul, J. Biofuels, biodiversity, and people: Understanding the conflicts and finding opportunities. Biol. Conserv. 2008, 141, 2450-2460. [CrossRef]

65. Crutzen, P.J.; Mosier, A.R.; Smith, K.A.; Winiwarter, W. $\mathrm{N}_{2} \mathrm{O}$ release from agro-biofuel production negates global warming reduction by replacing fossil fuels. Atmos. Chem. Phys. 2008, 8, 389-395. [CrossRef]

66. Kurowska, K.; Marks-Bielska, R.; Bielski, S.; Kryszk, H.; Jasinskas, A. Food security in the context of liquid biofuels production. Energies 2020, 13, 6247. [CrossRef]

67. Oniszk-Popławska, A.; Curkowski, A.; Wiśniewski, G.; Dziamski, P. Odnawialne źródła energii w gospodarstwie rolnym (Renewable energy sources on the farm). In Energia w Gospodarstwie Rolnym; Wyd. Wiatr s.c.: Warsaw, Poland, 2011 ; pp. 5-17. (In Polish)

68. Krajowy Ośrodek Wsparcia Rolnictwa. Rejestr Wytwórców Biogazu Rolniczego (Register of Agricultural Biogas Producers). 2020. Available online: http:/ / www.kowr.gov.pl/uploads/pliki/oze/biogaz/Rejestr\%20wytw\%C3\%B3rc\%C3\%B3w\%20biogazu\% 20rolniczego\%20z\%20dnia\%2017.04.2020\%20r..pdf (accessed on 18 January 2021). (In Polish)

69. Igliński, B.; Buczkowski, R.; Iglińska, A.; Cichosz, M.; Piechota, G.; Kujawski, W. Agricultural biogas plants in Poland: Investment process, economical and environmental aspects, biogas potential. Renew. Sustain. Energy Rev. 2012, 16, 4890-4900. [CrossRef]

70. Igliński, B.; Piechota, G.; Buczkowski, R. Development of biomass In Polish energy sector: An overview. Clean Technol. Environ. Policy 2015, 17, 317-329. [CrossRef] 
71. Jankowski, K.J.; Dubis, B.; Sokólski, M.M.; Załuski, D.; Bórawski, P.; Szempliński, W. Productivity and energy balance of maize and sorghum grown for biogas in a large-area farm in Poland: An 11-year field experiment. Ind. Crop. Prod. 2020, 148, 112326. [CrossRef]

72. Ministerstwo Gospodarki. Kierunki Rozwoju Biogazowni Rolniczych w Polsce w Latach 2010-2020 (Directions of Development of Agricultural Biogas Plants in Poland in 2010-2020). Dokument programowy; Ministerstwo Gospodarki: Warszaw, Poland, 2010. (In Polish)

73. Turowski, S.; Nowowiejski, N. Przyzagrodowa elektrownia wiatrowa źródłem taniej energii elektrycznej (A farmstead wind farm as a source of cheap electricity). Inż. Rol. 2010, 7, 215-222. (In Polish)

74. Forysiak, K. Ocena aktualnej sytuacji w odniesieniu do energetyki wiatrowej w Polsce: Możliwości rozwoju i jego zagrożenia (Assessment of the current situation in relation to wind energy in Poland: Development opportunities and its threats). Tech. Chłodnicza Klim. 2019, 3, 85-89. (In Polish)

75. Abromas, J. Some aspects of the assesment of visual impact of wind turbines on landscape of Western Lithuania. In Proceedings of the Fifth International Scientific Conference: Rural Development in Global Changes 2011, Aleksandras Stulginskis University, Kaunas, Lithuania, 24-25 November 2011; pp. 298-302. 